\title{
Judicial Review of Partial Arbitral Awards under Section 10(a)(4) of the Federal Arbitration Act
}

\author{
Jennifer M. Rhodes $\dagger$
}

Arbitration allows parties to partially contract out of the public judicial system and resolve their disputes in a contractually created forum. Recently, however, several federal courts have attempted to take back more power for themselves in the arbitration arena. In 1925, Congress enacted the Federal Arbitration Act ("FAA") to protect the integrity of arbitration clauses and ensure that a party could not evade the purpose of a contractual arbitration clause by trying to supplant the agreed-upon private judge with a federal judge. The FAA achieves this goal by greatly limiting the federal courts' ability to exercise jurisdiction over arbitral decisions. ${ }^{2}$ This ensures that courts do not frustrate one of the main purposes of arbitration by substituting their judgment for that of the decisionmaker selected by the parties. The FAA also limits when parties can seek judicial review by not allowing a court to review the case until the arbitrator has issued a judgment on the entire dispute. This prevents parties from shuttling back and forth between arbitrator and court and impeding a swift and streamlined dispute resolution.

Imagine that Company $\mathrm{A}$ enters into a contract to transport and deliver Company B's widgets to Merchant $\mathrm{C}$ and that this contract includes a clause in which the parties agree to submit all disputes arising from the contract to arbitration. After delivering the widgets, Company A sends Company B an invoice, requesting payment. Company $B$ refuses to pay anything, arguing that a portion of the goods was

$\dagger$ B.S. 1997; A.M. 2000, The University of Illinois-Urbana; J.D. Candidate 2003, The University of Chicago.

1 Federal Arbitration Act, Pub L No 25-401, 43 Stat 883 (1925), codified at 9 USC $\$ \S 1-16$ (2000)

2 See, for example, 9 USC $\S 3$ (requiring any suit or proceeding to be stayed if any issue involved is referable to arbitration); 9 USC $\$ 16$ (allowing appeals from a court decision not to compel arbitration, but not allowing appeals from a court decision to compel arbitration); 9 USC $\S 10$ (a) (providing limited grounds for vacating an arbitral award).

3 See, for example, 9 USC $\S 10$ (a)(4) states that a court may vacate an arbitral award if the arbitrators so "exceeded their powers" or "imperfectly executed them" that a "mutual, final, and definite" award is not possible. Courts have held this explicitly to mean that an award will not be enforced unless final. See, for example, United Transportation Union $v$ Gateway Western Railway Co, 284 F3d 710, 713 (7th Cir 2002) ("The Federal Arbitration Act is explicit that an award is unenforceable unless final, 9 USC $\$ 10(a)(4)$.").

4 See Part I.A. 
damaged in shipment. After the parties enter into arbitration, the arbitrator first decides that Company A must be paid in full for the widgets successfully delivered. Before the arbitrator can decide the remaining claims, however, Company B goes to federal court to have the partial award vacated. Should a court be able to exercise jurisdiction over Company B's claim?

The FAA requires that courts give broad deference to an arbitrator's decisions and decline to review the arbitrator's awards until he or she has issued a final judgment. Under the longstanding judicial interpretation of what constitutes a final arbitral award as required by 9 USC $\$ 10(a)(4)$-an interpretation that consciously tracks the final judgment rule-partial awards may not be enforced. Recently, however, some courts have adopted a more flexible understanding of finality. In doing so, they have exercised jurisdiction over claims by parties seeking to enforce partial arbitral awards. These courts reason that a strict definition of finality might actually impede the swift resolution of arbitral disputes by making the parties wait for enforcement of a ruling on one issue until the arbitrator has ruled on the other issues in the case. They support the exercise of jurisdiction over the partial awards by drawing analogies to FRCP 54(b), which permits interlocutory review of a district court order when such review furthers the twin goals of expediency and judicial efficiency.

In this Comment, however, I outline several reasons why courts should adhere to the longstanding rule forbidding interlocutory review and not loosen the finality requirement embodied in Section 10(a)(4). First, the analogy between a court's review of a partial arbitral award and an appellate court's review of a district court's partial judgment is inapt. While Rule 54(b) expressly grants appellate courts the power to review district courts' partial judgments, the FAA makes no corresponding grant of authority to courts to review partial arbitral awards. Second, the relaxed approach to arbitral finality undermines

\section{$5 \quad$ FRCP 54(b) provides:}

When more than one claim for relief is presented in an action, whether as a claim, counterclaim, cross-claim, or third-party claim, or when multiple parties are involved, the court may direct the entry of a final judgment as to one or more but fewer than all of the claims or parties only upon an express determination that there is no just reason for delay and upon an express direction for the entry of judgment. In the absence of such determination and direction, any order or other form of decision, however designated, which adjudicates fewer than all the claims or the rights and liabilities of fewer than all the parties shall not terminate the action as to any of the claims or parties, and the order or other form of decision is subject to revision at any time before the entry of judgment adjudicating all the claims and the rights and liabilities of all the parties.

(emphasis added). 
the goal of deference to arbitrators. Third, arbitration is a creature of contract, and courts should not "rewrite" the contract ex post.

In Part I, I examine the motivation behind the FAA, the benefits of arbitration, and the finality requirement for judicial review. In Part II, I scrutinize the caselaw that has recently deviated from the finality requirement. Finally, in Part III, I recommend that courts should not loosen the finality requirement because there is no congressional authorization to do so, and such an interpretation would undermine Congress's pro-arbitration policy. Furthermore, the parties can always contract around anticipated problems by explicitly providing for interlocutory review.

\section{THE FEDERAL ARBitRation ACT}

Before analyzing the arguments for and against interlocutory appeals of arbitration, one must understand the background of the FAA, as well as the proper role of the courts to promote arbitration. Federal policy is pro-arbitration, and this policy may be properly promoted only by limiting the instances in which courts can intervene.

\section{A. Arbitration}

Originally passed in 1925, the FAA was designed by Congress to allow parties to avoid "the costliness and delays of litigation" time of severe judicial hostility to arbitration, to place arbitration agreements "upon the same footing as other contracts." The Supreme Court has repeatedly acknowledged - as recently as January $2002^{\circ}-$ that judicial hostility to arbitral agreements was the primary motivation for the Act's passage and that the avoidance of costs and delays was merely secondary. ${ }^{10}$ Since the passage of the FAA, federal policy has consistently encouraged arbitration and has directed courts to re-

6 Scherk v Alberto-Culver Co, 417 US 506, 510-11 (1974).

7 Gilmer $v$ Interstate/Johnson Lane Corp, 500 US 20, 24 (1991) (noting that the FAA was enacted to "reverse the longstanding judicial hostility to arbitration agreements that had existed at English common law and had been adopted by American courts").

8 To Validate Certain Agreements for Arbitration, HR Rep No 96, 68th Cong, 1st Sess 1-2 (1924) ("[T]he jealousy of the English courts for their own jurisdiction ... survived for so lon $[\mathrm{g}]$ a period that the principle became firmly embedded.... The courts have felt that the precedent was too strongly fixed to be overturned without legislative enactment."). See also To Make Valid and Enforceable Certain Agreements for Arbitration, S Rep No 536, 68th Cong, 1st Sess 2-3 (1924) (describing the need and benefits of enforceable arbitration awards).

9 See EEOC v Waffle House, Inc, 534 US 279, 289 (2002).

10 Dean Witter Reynolds, Inc v Byrd, 470 US 213, 220-21 (1985) ("[P]assage of the Act was motivated, first and foremost, by a congressional desire to enforce agreements into which parties had entered, and we must not ... allow the fortuitous impact of the Act on efficient dispute resolution to overshadow the underlying motivation."). See also Part II.A. 
solve any questions concerning the scope of arbitrable issues on the side of arbitrability."

Given the importance that Congress places on providing parties with the opportunity to arbitrate, it is useful to consider how parties may benefit from arbitration. Congress encourages arbitration because it has many qualities that make it a valuable alternative to litigation." The hallmarks of arbitration, "access to expertise"13 and "adaptability," are hard to find in traditional litigation. Because arbitration is a private system of justice that is entered into voluntarily via contract, ${ }^{15}$ parties can tailor their dispute resolution to their specific commercial needs. ${ }^{16}$ For example, parties can contract over what issues will be arbitrated, ${ }^{17}$ the choice of forum, ${ }^{18}$ the type of arbitrator to pre-

11 See Moses H. Cone Memorial Hospital v Mercury Construction Corp, 460 US 1, 24 (1983) (noting that the FAA manifests "a liberal federal policy favoring arbitration agreements").

12 Of course it should be noted that there can also be a downside to arbitration. One common concern is that when an experienced player in arbitration (such as a large manufacturer) arbitrates with a novice (such as a small supplier), the experienced player will have an advantage by being more familiar with the system and because the arbitrator may tend to favor the experienced player in order to get repeat business. However, given that arbitration agreements are voluntarily entered into, there is a presumption that the benefits outweigh the downside.

13 An example where expertise is important is in labor relations. See Lon L. Fuller, Collective Bargaining and the Arbitrator, 1963 Wis L Rev 3,11:

Labor relations have today become a highly complicated and technical field. ... It has developed its own vocabulary.... In the nature of things few judges can have had any very extensive experience in the field of industrial relations. Arbitrators, on the other hand, are compelled to acquire a knowledge of industrial processes, modes of compensation, complex incentive plans, job classifications, shift arrangements, and procedures for layoff and recall.

14 "The presentation of evidence and argument in litigation is governed by rules of procedure and evidence enacted by the government. In contrast, the rules of procedure and evidence in arbitration are, with few exceptions, whatever the contract says they are." Stephen J. Ware, $A l$ ternative Dispute Resolution $\$ 2.3$ (c) at 21 (West 2001).

15 See IDS Life Insurance Co v Royal Alliance Association, Inc, 266 F3d 645, 649 (7th Cir 2001 ) (referring to the "voluntary contractual nature" of commercial arbitration). Form contracts that contain "take-it-or-leave-it" propositions requiring arbitration are considered voluntary agreements for purposes of the FAA. See Metro East Center for Conditioning and Health $v$ Qwest Communications International, Inc, 294 F3d 924,926 (7th Cir 2002).

16 See Volt Information Sciences, Inc $v$ Board of Trustees of Leland Stanford Junior University, 489 US 468,479 (1989) (Parties may "specify by contract the rules under which [the] arbitration will be conducted."). See also Baravati v Josephthal, Lyon \& Ross, Inc, 28 F3d 704, 709 (7th Cir 1994) ("[S]hort of authorizing trial by battle or ordeal or ... a panel of three monkeys, parties can stipulate to whatever procedures they want to govern the arbitration of their disputes; parties are as free to specify idiosyncratic terms of arbitration as they are to specify any other terms in their contract.").

17 See Mastrobuono v Shearson Lehman Hutton, Inc, 514 US 52, 57 (1995) ("[P]arties are generally free to structure their arbitration agreements as they see fit. ... [T] contract the issues which they will arbitrate.").

18 See In re Salomon Inc Shareholders Derivative Litigation 91, 68 F3d 554, 558-59 (2d Cir 1995 ) (stating that several circuits, the Second Circuit included, have held that contracts contain- 
side, ${ }^{19}$ how much discovery to allow, ${ }^{20}$ the schedule, ${ }^{21}$ the length of the hearing, and what rules of evidence to follow. ${ }^{23}$ Parties can also choose whether they want the arbitrator to issue an opinion or just the outcome. ${ }^{24}$

In choosing the type of arbitrator desired, the parties can choose an expert in the subject matter being disputed. An expert is often preferred to a jury, which may not understand complex technical issues, or a judge, who is by necessity a generalist. ${ }^{25}$ When both parties are confident that any potential disputes will be resolved by an industry expert who understands the background of the dispute, and therefore will make decisions more efficiently and more accurately than a judge, the range of contractual possibilities greatly expands. ${ }^{26}$ Also, allowing those with expertise to decide the dispute indirectly benefits the pub-

ing clauses requiring arbitration in accordance with the rules of some private organization are designating the private organization as the exclusive arbitral forum).

19 See Gateway Coal Co v United Mine Workers of America, 414 US 368, 379 (1974) ("[P]arties are always free to choose an arbitrator whose knowledge and judgment they trust."). There is often a requirement that the arbitrator in a maritime dispute be a "commercial man." See W.K. Webster \& Co v American President Lines, Ltd, 32 F3d 665, 668 (2d Cir 1994) ("[T]he charter party required the arbitrators to be "commercial men conversant with shipping matters." ).

20 See American Arbitration Association, Commercial Dispute Resolution Procedures, Section L-5(c), online at http://www.adr.org/index2.1.jsp?JSPssid=15747 (visited Jan 30, 2003) ("The parties may conduct such document discovery as may be agreed to by all the parties provided, however, that the arbitrator(s) may place such limitations on the conduct of such discovery as the arbitrator(s) shall deem appropriate.").

21 Henry M. Hart, Jr. and Albert M. Sacks, The Legal Process: Basic Problems in the Making and Application of Law 310 (Foundation 1994) (William N. Eskridge, Jr. and Philip P. Frickey, eds):

Within broad limits ... private parties who submit an existing dispute to arbitration may write their own ticket about the terms of submission, if they can agree to a ticket. ... The arbitration of an existing dispute is the parties' dream, and they can make it what they want it to be.

22 See In re A.H. Robins Co, Inc, 42 F3d 870, 874 (4th Cir 1994) (upholding arbitration provisions including terms "describ[ing] the choosing of a panel of arbitrators, [and] the length of their services").

23 See Volt, 489 US at 479 ("Just as [the parties] may limit by contract the issues which they will arbitrate, so too may they specify by contract the rules under which that arbitration will be conducted.") (citation omitted).

24 See United Steelworkers of America v Enterprise Wheel \& Car Corp, 363 US 593, 598 (1960) ("Arbitrators have no obligation to the court to give their reasons for an award.").

25 See Commonwealth Coating Corp v Continental Casualty Co, 393 US 145, 150 (1968) (White concurring) ("It is often because [arbitrators] are men of affairs, not apart from but of the marketplace, that they are effective in their adjudicatory function.").

26 See Lisa Bernstein, Private Commercial Law in the Cotton Industry: Creating Cooperation through Rules, Norms, and Institutions, 99 Mich L Rev 1724, 1741 (2001). 
lic courts by diverting some of the more technical and esoteric disputes. $^{27}$

Arbitration reduces the cost and length of litigation. Parties who agree to arbitrate trade "the procedures and opportunity for review of the courtroom for the simplicity, informality, and expedition of arbitration. ${ }^{, 28}$ There is typically less discovery than in regular litigation; procedures are informal; there are fewer motions; the hearings are shorter; and appeals are limited. Therefore, arbitration will often proceed more quickly than litigation. While a typical employment dispute takes 2.5 years to resolve in court, ${ }^{29}$ the average arbitration takes 8.6 months.

There is a greater degree of privacy in arbitration. In litigation, sensitive information normally becomes part of the public record. ${ }^{31}$ Courts rarely grant motions to seal this information, even if the parties had previously entered into a secrecy agreement. ${ }^{32}$ With arbitration, the existence of the dispute can be kept private, including the nature of the claims and allegations, as well as the documents and testimony. This prevents the dispute from ending up on the front page of The Wall Street Journal. More importantly, in the commercial context, it prevents a party's opponent from learning its financial bottom line. If, for example, Company $\mathrm{A}$ is a manufacturer and is in a dispute with Company B, one of its repeat customers, Company A would not want Company B to have access to Company A's actual costs for the good produced. Such knowledge adversely affects Company A's bargaining position in the future. When litigating in the courts, it is not only Com-

27 See Conticommodity Services, Inc v Philipp \& Lion, 613 F2d 1222, 1224 (2d Cir 1980) (noting that arbitration "eases the workload of the courts").

28 Gilmer, 500 US at 31 (1991).

29 See Hooters of America, Inc v Phillips, 173 F3d 933, 936 (4th Cir 1999).

30 See Lewis L. Maltby, Private Justice: Employment Arbitration and Civil Rights, 30 Colum Hum Rts L Rev 29, 55 (1998).

31 See Nixon v Warner Communications, Inc, 435 US 589, 597 (1978) ("The courts of this country recognize a general right to inspect and copy public records and documents, including judicial records and documents. [This right is not limited to those with] a proprietary interest in the document or ... need for it as evidence in a lawsuit.") (citations omitted).

32 Public access is important "to appreciate fully the often significant events at issue in public litigation and the workings of the legal system." Newman $v$ Graddick, 696 F2d 796, 802 (11th Cir 1983). "Not only the legislature but also students of the judicial system are entitled to know what the heavy financial subsidy of litigation is producing." Baxter International, Inc $v A b$ bott Laboratories, 297 F3d 544, 547 (7th Cir 2002). For this reason, dispositive documents to a court proceeding cannot be kept secret, even if both parties agree to secrecy. See id.

33 Closed arbitration is "a sure path to dispute resolution with complete confidentiality." Baxter, 297 F3d at 548. 
pany $B$ that will have access to this information, if dispositive of the dispute, but potentially all buyers and fellow competitors.

In an effort to promote arbitration, the FAA purposefully limits the ability of courts to review arbitral awards. ${ }^{35}$ The less involved courts are in the process, the more parties will see arbitration as a viable alternative to litigation. While the FAA authorizes federal courts to enforce arbitral awards, ${ }^{36}$ it greatly limits the grounds on which a court can vacate an arbitral award. These grounds are generally wholly divorced from the merits of an arbitrator's decisions so as to avoid the danger of undermining the integrity of the arbitral process. The narrow scope of review preserves the benefits that arbitration offers and "prevent[s] arbitration from becoming a 'preliminary step to judicial resolution.","37

\section{B. Finality Requirement under the FAA}

By restricting when courts may review arbitrators' decisions, Congress prevented courts from substituting their judgment for that of the arbitrators. The FAA prevents parties from shuttling back and forth between the arbitrator and court, frustrating the effort to achieve a swift and streamlined resolution of the dispute. This Part discusses the finality requirement under Section 10(a)(4) of the FAA.

The final judgment rule has its roots in English common law jurisprudence, and has been a part of our American system since the Judiciary Act of $1789 .^{38}$ The FAA finality requirement provides the same benefits that the final judgment rule historically has provided, such as

34 For a general discussion of the importance of privacy in industry settings, see Omri BenShahar and Lisa Bernstein, The Secrecy Interest in Contract Law, 109 Yale L J 1885 (2000).

35 See Parts I.A and I.B.1.

36 The federal courts have jurisdiction only over contracts involving interstate commerce or maritime transactions. 9 USC $\S 2$ states that all written arbitration provisions in "any maritime transaction or a contract evidencing a transaction involving commerce" are "valid, irrevocable, and enforceable [in federal court], save upon such grounds as exist at law or in equity for the revocation of any contract." 9 USC $\S 1$ defines "maritime transactions" and "commerce" and notes that the FAA will not apply to "contracts of employment of seamen, railroad employees, or any other class of workers engaged in foreign or interstate commerce."

37 Eljer Manufacturing v Kowin Development Corp, 14 F3d 1250, 1254 (7th Cir 1994). See also Barbier v Shearson Lehman Hutton, Inc, 948 F2d 117, 120 (2d Cir 1991) ("It is well-settled that judicial review of an arbitration award is narrowly limited."); Eljer, 14 F3d at 1254 ("Arbitration does not provide a system of 'junior varsity trial courts' offering the losing party complete and rigorous de novo review."), citing National Wrecking $v$ International Brotherhood of Teamsters, Local 731, 990 F2d 957, 960 (7th Cir 1993).

38 Sections 21,22 , and 25 required final judgments before an appeal could be taken, and no interlocutory appeals were allowed. For a general discussion on the history of the final judgment rule, see Carleton M. Crick, The Final Judgment as a Basis for Appeal, 41 Yale L J 539, 548-51 (1932). 
avoiding the waste of judicial resources and not allowing parties to delay justice or harass the other side by using seriatim appeals. Over time, there have been a few exceptions to the finality requirement in our legal system, but the large majority of these exceptions are statutory. Of those, FRCP 54(b) is the most relevant for our purposes because the courts that have applied a loosened finality requirement under the FAA have done so by analogy to this rule.

\section{The FAA's finality requirement: 9 USC $\S 10(a)(4)$.}

One way of narrowing the scope of judicial review, and hence promoting arbitration, is to impose a finality requirement for judicial review of arbitral awards. Section 10(a) lists the limited instances in which a federal court can vacate an arbitral award: (1) where the award was procured by "corruption, fraud, or undue means;" (2) where there was "evident partiality" or "corruption in the arbitrators;" (3) where there was "misconduct" or "misbehavior" on the part of the arbitrator; and (4) where the arbitrators "exceeded their power" or so "imperfectly executed" them that a "mutual, final, and definite" award is not possible and the time within which the agreement required the award to be made has not expired. ${ }^{39}$

Courts have interpreted Section 10(a)(4), which requires a "mutual, final, and definite" award, to impose a finality requirement on judicial review of such awards because a vacatur is only appropriate under Section 10(a)(4) when arbitrators "imperfectly execute" their powers and issue an award purported to be final but which, in fact, is not. ${ }^{40}$ Although Congress could have made the finality requirement more explicit by not inserting it in the midst of a list of grounds on which an arbitrator's decision can be vacated, the courts have found the language of the Act to be unambiguous on this point. ${ }^{41} \mathrm{~A}$ "final" award means that arbitration must be "complete", and "not interlocu-

399 USC $\S 10(\mathrm{a})(1)-(4)$.

40 See Michaels v Mariforum Shipping, SA, 624 F2d 411, 414 (2d Cir 1980). The court also noted: "That section has no application to an interim award that the arbitrators did not intend to be their final determination on the issues submitted to them." Id.

41 See id:

[I]t is only after an award has been made by the arbitrators that a party can seek to attack any of the arbitrators' determinations in court.... [A] district court is without authority to review the validity of arbitrators' rulings prior to the making of an award. Where ... arbitrators make an interim ruling that does not purport to resolve finally the issues submitted to them, judicial review is unavailable.

42 See Local 36, Sheet Metal Workers Intl Assoc, AFL-CIO v Pevely Sheet Metal Co, Inc, 951 F2d 947, 949-50 (8th Cir 1992). 
tory," ${ }^{43}$ which in turn means that the arbitrator must have already decided all issues presented, including both liability and damages." Combined with the term "mutual," it means that all issues involving all parties have been decided. "Definite" means that "the award is sufficiently clear and specific to be enforced should it be confirmed by the district court and thus made judicially enforceable." have deviated from strict adherence to the final judgment rule, they have done so by playing with the definitions of these terms - not by attacking whether the FAA has a finality requirement for judicial jurisdiction.

2. The final judgment rule.

The final judgment rule has long been a part of our American jurisprudence because of the benefits it provides to the legal system. Congress adopted the same finality requirement, incorporated in Section $10(\mathrm{a})(4)$ of the FAA, to maintain those benefits. Historically, courts have stringently enforced the FAA's finality requirement in the same way they have enforced the final judgment rule. ${ }^{47}$ In other words, a district court can only enforce an arbitral award under the same circumstances that a court of appeals can review a judgment of the district court-if the decision disposes of all claims involving all parties on the merits. For many decades, the interpretation of arbitral finality has tracked the definition of finality provided by the final judgment rule.

43 El Mundo Broadcasting Corp v United Steelworkers of America, AFL-CIO, 116 F3d 7, 9 (1st Cir 1997).

44 See Michaels, 624 F2d at 413-14.

45 IDS Life Insurance, 266 F3d at 650.

46 See Part II.A. All courts adhere to a finality requirement to some degree. As some circuits adopt looser definitions of finality, however, we should expect to see an increased number of published opinions, such as IDS Life Insurance, addressing the final judgment rule in more detail.

47 See Millmen Local 550, United Brotherhood of Carpenters and Joiners of America, AFLCIO v Wells Exterior Trim, 828 F2d 1373, 1375 (9th Cir 1987):

To allow judicial intervention prior to the final award would contravene the fundamental federal ... policy of deference to contractual dispute resolution procedures. ... Moreover, interlocutory review of nonfinal arbitration awards would defeat the purpose of 28 USC $\S 1291$ (1982) to avoid piecemeal litigation of a claim.

(citations omitted). Millmen Local was governed by the Labor Management Relations Act, but "federal courts rely on FAA cases to inform their LMRA analysis." Providence Journal Co v Providence Newspaper Guild, 271 F3d 16, 19 n 3 (1st Cir 2001), citing United Paperworkers International Union v Misco, Inc, 484 US 29, 40 n 9 (1987). 
The well-accepted purpose of the final judgment rule is to avoid wasting judicial resources. ${ }^{48}$ Multiple appeals for the same case take up appellate judges' time, and the issues the appellate court decides may become moot by decisions on later issues. ${ }^{50}$ The final judgment rule also keeps litigants from using seriatim appeals as a tool of delay or harassment. ${ }^{\text {s1 }}$ Exceptions to this rule, such as FRCP 54(b), are therefore to be granted neither lightly nor routinely. ${ }^{52}$ The Supreme Court frequently has noted that this requirement "is not one of those technicalities to be easily scorned. It is an important factor in the smooth working of our federal system." "The finality requirement of the FAA therefore serves a twofold purpose: It protects Congress's proarbitration policy by preventing courts from unduly interfering in private contract in the face of judicial hostility toward arbitration ${ }^{\text {s4 }}$ and streamlines the process, for example by preventing parties from shuttling back and forth between the arbitrator and court.

\section{Exceptions to the final judgment rule.}

The promulgation of the Federal Rules of Civil Procedure, which formed a new "civil action" that is wide in scope, created a need to carve out some exceptions to the final judgment rule. ${ }^{55}$ Under the new rules, ${ }^{56}$ the number of claims and parties within the same case grew ex-

48 See Stringfellow v Concerned Neighbors in Action, 480 US 370, 380 (1987).

49 See New York State National Organization for Women v Terry, 886 F2d 1339, 1349 (2d Cir 1989) ("[I]t is a waste of judicial resources for two courts to be considering the same issues in the same case at the same time."), citing Griggs v Provident Consumer Discount Co, 459 US 56, 58 (1982).

50 See Fox v Baltimore City Police Department, 201 F3d 526, 530 (4th Cir 2000).

51 See Flanagan v United States, 465 US 259, 263-64 (1984); Firestone Tire \& Rubber Co $v$ Risjord, 449 US 368, 374 (1981), quoting Cobbledick v United States, 309 US 323, 325 (1940).

52 See Curtiss-Wright Corp v General Electric Co, 446 US 1, 8-10 (1980) ("Not all final judgments on individual claims should be immediately appealable, even if they are in some sense separable from the remaining unresolved claims. ... Plainly, sound judicial administration does not require that Rule 54(b) requests be granted routinely.").

53 Jefferson $v$ City of Tarrant, 522 US 75, 81 (1997), quoting Radio Station WOW v Johnson, 326 US 120, 124 (1945).

54 See Part I.A.

55 FRCP 54(b), Advisory Committee Note to the 1946 Amendments:

Rule 54(b) was originally adopted in view of the wide scope and possible content of the newly created 'civil action' in order to avoid the possible injustice of a delay in judgment of a distinctly separate claim to await adjudication of the entire case. It was not designed to overturn the settled federal rule [prohibiting piecemeal disposal of litigation except in special instances covered by statute.

56 The Federal Rules of Civil Procedure were first promulgated in 1938, when Congress enacted the Rules Enabling Act, 28 USC \$ 2072, authorizing the Supreme Court to promulgate procedural rules. The Supreme Court, in turn, delegated its authority to committees of the Judicial Conference, which is a supervisory and administrative arm of the federal courts. 
ponentially. ${ }^{57}$ The rulemakers were particularly concerned with the potential delays in justice resulting from the rigidity of the final judgment rule, ${ }^{58}$ and therefore sought to fashion a few well-defined exceptions to the final judgment rule. ${ }^{59}$ These exceptions include 28 USC $\S 1292$, which allows interlocutory appeals in limited circumstances; ${ }^{60}$ 28 USC $\S 1651$, which authorizes grants of extraordinary writs of mandamus; ${ }^{61}$ FRCP 23(f), which allows interlocutory appeals for class certification orders at the discretion of the appellate court; ${ }^{.2}$ and the collateral order doctrine, which allows orders to be considered final if the order will "be effectively unreviewable on appeal from a final judgment."

The exception that bears the most on piecemeal appeals of arbitral orders is the one created by FRCP 54(b). ${ }^{64}$ This rule recognizes that under a particular set of circumstances, the purposes of the final

57 See, for example, Commission on Structural Alternatives for the Federal Courts of Appeals, HR Rep No 105-26, 105th Cong, 1st Sess 2 (1997) ("Over the past two decades, filings in the courts of appeals have increased by more than 200 percent.").

58 FRCP 54(b), Advisory Committee Note to the 1946 Amendments ("Rule 54(b) was originally adopted in view of the wide scope and possible content of the newly created 'civil action' in order to avoid the possible injustice of a delay in judgment of a distinctly separate claim to await adjudication of the entire case.").

59 For a general discussion, see Timothy P. Glynn, Discontent and Indiscretion: Discretionary Review of Interlocutory Orders, 77 Notre Dame L Rev 175, 185-201 (2001).

60 Section 1292(a)(1) allows interlocutory appeals from orders "granting, continuing, modifying, refusing or dissolving injunctions, or refusing to dissolve or modify injunctions." Sections 1292(a)(2) and (a)(3) allow interlocutory appeals for orders dealing with receiverships and determinations of rights and liabilities in admiralty cases respectively. Section 1292(b) allows an interlocutory appeal with the permission of both the district court judge and court of appeals for orders involving a "controlling question of law as to which there is substantial ground for difference of opinion." In reality, $\$ 1292$ (b) is used very rarely. In 1989 , there were roughly 40,000 federal appeals filed. See Diana G. Culp, The Judiciary: Fixing the Federal Courts, 76 ABA J 63, 63 (June 1990). That year, only 330 interlocutory appeals were certified by district courts, and only 118 of those were accepted by appellate courts. See Michael Solomine, Revitalizing Interlocutory Appeals in the Federal Courts, 58 Geo Wash L Rev 1165, 1176 (1990) (Tabie 1a).

61 Such writs are given "sparingly and only in the most critical and exigent circumstances." Brown v Gilmore, 533 US 1301, 1305 (2001), quoting Fishman v Schaffer, 429 US 1325, 1326 (1976). See also US S Ct Rule 20.1 ("Issuance by the Court of an extraordinary writ authorized by 28 USC $\$ 1651$ (a) is not a matter of right, but of discretion sparingly exercised.").

62 FRCP 23(f).

63 Cunningham v Hamilton County, 527 US 198, 206 (1999). For an in-depth discussion of the collateral order doctrine, see Jeffrey D. Hanslick, Decisions Denying the Appointment of Counsel and the Final Judgment Rule in Civil Rights Litigation, 86 Nw U L Rev 782, 791-806 (1992).

\section{FRCP 54(b) states:}

When more than one claim for relief is presented in an action, whether as a claim, counterclaim, cross-claim, or third-party claim, or when multiple parties are involved, the court may direct the entry of a final judgment as to one or more but fewer than all of the claims or parties only upon an express determination that there is no just reason for delay and upon an express direction for the entry of judgment. 
judgment rule-expedience and judicial efficiency-can best be served by allowing exceptions to the rule. One can imagine situations in which claims in a lawsuit are sufficiently unrelated that the disposition of one claim would not affect the disposition of others. In such situations, delaying the appeal and final resolution of an interlocutory order deciding such a claim would serve no purpose and could, indeed, cause useless delay. ${ }^{65}$ Thus, the 1946 amendment to FRCP 54(b) allows a district court, in a case with multiple claims, to enter a final judgment to dispose of one or fewer than all of the claims for review, but "only upon an express determination that there is no just reason for delay and upon an express direction for the entry of judgment." ${ }^{, 66}$ In 1961, FRCP 54(b) was amended to allow the district court not only to enter a final judgment for "one or more but fewer than all" of the claims, but also for one or more but fewer than all of the parties."

FRCP 54(b) contains an important safeguard: It mandates that the district court must certify that there is no just reason for delay. This certification requirement allows district judges to retain control over their own cases and decide when piecemeal review is beneficial. This is important because it reduces the chance that the appellate court will be given an issue to decide that, if reversed, could have an adverse affect on the rest of the proceedings remaining before the district judge.

\section{DEVIATIONS FROM THE FINALITY REQUIREMENT OF SECTION 10(a)(4)}

In recent years, a few courts of appeal have departed from the strict finality requirement ${ }^{69}$ and have allowed appeals of partial arbitral awards for those claims viewed as independent from the remaining claims still before the arbitrator. These courts justify their decisions by relying on the rationales supporting FRCP 54(b). They emphasize that it makes little sense not to enforce part of an award if it is

65 The Advisory Committee Notes to the 1946 Amendment of FRCP 54(b) recognized this and stated that the rule was intended to ensure that parties did not have to "await adjudication of the entire case."

66 FRCP 54(b).

67 Id.

68 Id. The change was made because "[t]he danger of hardship through delay of appeal until the whole action is concluded may be at least as serious in the multiple-parties situations as in multiple-claims cases." FRCP 54(b), Advisory Committee Notes to the 1961 Amendments.

69 See, for example, Publicis Communication v True North Communications, Inc, 206 F3d 725 (7th Cir 2000) (affirming that the arbitration tribunal's decision was final, despite the fact that unrelated issues had not yet been arbitrated); Metallgesellschaft $A G \vee M / V$ Capitan Constante, $790 \mathrm{~F} 2 \mathrm{~d} 280$ (2d Cir 1986) (allowing for an appeal of an arbitral award despite the fact that claims "separate and independent" from the issue at hand remained before the arbitrators). 
factually and conceptually unrelated to the other claims that remain before the arbitrators. These courts note that one reason arbitration is preferred over litigation is because of the expectation that it will be less expensive. ${ }^{70}$ If interlocutory review of the issues is not allowed, they reason, it will cost the parties more money and time. Only a few circuit courts have deviated from the finality requirement, and at least one of those circuits - the Seventh - has recently expressed misgivings about its departure from strict adherence to the final judgment rule regarding arbitral awards.

Part A reviews Second and Seventh Circuit cases in which courts most significantly have departed from the finality requirement for judicial review of partial arbitral awards. Part B then examines a series of First Circuit cases in which the parties agreed to bifurcate arbitration into two distinct phases: an initial phase resolving liability and a second phase awarding damages. In such cases, the First Circuit permits judicial review of arbitral awards, even when only one of the phases of arbitration has been completed. In doing so, however, it relies on precedent that is unconvincing and not on point. An agreement to bifurcate the proceeding into two distinct phases does not mean that the parties have agreed to interlocutory review.

\section{A. Cases Relaxing the FAA's Finality Requirement}

The Second Circuit was the first circuit court to adopt a relaxed interpretation of the finality requirement. Previously, the Second Circuit interpreted the finality rule strictly, stating that in order for an arbitral award to be considered final it had to be "intended by the arbitrators to be their complete determination of all claims submitted to them ... not only [as to] liability, but also ... damages." "The court's position changed, however, with its decision in Metallgesellschaft $A G v$ $M / V$ Capitan Constante, ${ }^{2}$ in which it argued that when necessary, the final judgment rule could be deviated from in order to meet the purpose of arbitration. ${ }^{73}$

\footnotetext{
70 See Metallgesellschaft, $790 \mathrm{~F} 2 \mathrm{~d}$ at 282.

Michaels v Mariforum Shipping, SA, 624 F2d 411, 413-14 (2d Cir 1980).

790 F2d 280 (2d Cir 1986).

Id at 282:
}

[T] he purpose of arbitration is to permit a relatively quick and inexpensive resolution of contractual disputes ... [and it] would be a perversion of the salutary design for a [party] to be denied the same prompt and commercially important relief from an arbitration panel that it could have received from a court. 
Metallgesellschaft involved a dispute arising out of a shipping contract for fuel oil. The ship Capitan Constante transported and delivered freight for Metallgesellschaft, but Metallgesellschaft did not pay, alleging short delivery and fuel contamination. ${ }^{74}$ In keeping with their contract, the parties entered into arbitration, in which the arbitration panel made a partial award in favor of Capitan Constante for the value of the unpaid freight. ${ }^{75}$ The Second Circuit took jurisdiction over the case and upheld enforcement of the partial arbitral award, even though the panel had not yet decided the other issues before it. $^{76}$ The court was motivated to assert jurisdiction based on the strength of the underlying claim. ${ }^{77}$ It emphasized that if the claim had been brought in a court of law instead of arbitrated, Capitan Constante would undoubtedly be entitled to summary judgment for the amount of the unpaid freight. ${ }^{78}$ The court considered it "a perversion" that resolution of a claim could occur more quickly in litigation than in arbitration. ${ }^{79}$ The court stated that fairness required prompt payment because the goal of arbitration is to permit quick and inexpensive resolution of contractual disputes. ${ }^{80}$ Therefore, it held that the issue of whether Metallgesellschaft was liable for the freight was an independent issue from the payment. ${ }^{81}$ In a dissent, Judge Wilfred Feinberg wrote that courts should not create exceptions to the final judgment rule for arbitration because such an action requires congressional approval. ${ }^{82}$ Furthermore, he reasoned, while hearing the case at bar might result in speedier resolution of one party's claims, the long-term effect of allowing piecemeal judicial review would be to "make arbitration more complicated, time consuming and expensive " with an increasing number of parties demanding such review.

74 Id at 281 .

75 Id.

76 See id at 282.

77 See, for example, id at 281 ("It is a rule of ancient vintage that, where freight is payable on delivery, it should be paid concurrently with the delivery of the goods.").

78 See id at 282.

79 Id.

80 See id, referring to Diapulse Corp v Carba, Ltd, 626 F2d 1108, 1110 (2d Cir 1980).

81 See id.

82 Metallgesellschaft, $790 \mathrm{~F} 2 \mathrm{~d}$ at 284 (Feinberg dissenting):

The exception to the final judgment rule now embodied in Rule 54(b) required the approval of Congress. That body should do the amending of the arbitration statute to provide a separate and independent claim exception to the finality requirement of section $[10(a)(4)]$, if it finds such an amendment consistent with the goals of the arbitration statute.

83 Id at 285. Judge Feinberg went on to say:

After this decision, use of partial final awards will doubtless increase and, if the successful parties can get partial awards confirmed by the district courts, it stands to reason that they 
The Seventh Circuit has also allowed judicial review of a partial arbitral award, based on the same policy arguments made in Metallgesellschaft. In Publicis Communication v True North Communications, $I n c,{ }^{84}$ two parties entered into a joint venture and agreed to arbitrate almost all disputes arising from their partnership. After their joint venture fell apart, the parties entered into arbitration. One of the issues submitted for arbitration was whether Publicis had to turn over its tax records to True North. ${ }^{86}$ Despite an order from the arbitrator to turn over these records, Publicis refused. ${ }^{87}$ In response, True North filed a claim in federal court to have the arbitrator's order enforced. ${ }^{88}$

The court held that an arbitral order requiring one party to hand over its tax records to the other party would be treated as a final order, and hence reviewable, because considered in isolation, the order was final ${ }^{89}$ despite the fact that the order did not end the arbitration. The court justified its decision by saying that while "[a]rbitration can be an effective way to resolve a dispute in less time, at less expense, and with less rancor than litigating in the courts[,] [a]rbitration loses some of its luster ... when one party refuses to abide by the outcome and the courts are called in after all for enforcement."

The Seventh Circuit has recently questioned the legitimacy of this reasoning. In IDS Life Insurance Co v Royal Alliance Association, the court criticized the Publicis decision. The court noted that while decisions such as Publicis employ a regime similar to the one that Rule 54 (b) creates for federal litigation, this regime "is in tension with the absence from the Federal Arbitration Act of any counterpart to that rule." The IDS Life Insurance court stressed that "final" and "mutual" mean "that the arbitrators ... have resolved the entire dispute (to the extent arbitrable) that had been submitted to them.",93

will do so.... It will make arbitration more like litigation, a result not to be desired. Id.

206 F3d 725 (7th Cir 2000).

85 Id at 727.

86 Id.

87 Id.

88 Id.

89 Id at 729.

90 Id at 727. The court cited an earlier Seventh Circuit case, Yasuda Fire \& Marine Insurance Co of Europe, Ltd v Continental Casualty Co, 37 F3d 345, 348 (7th Cir 1994), which relied on a holding in the Ninth Circuit. See Pacific Reinsurance Management Corp v Ohio Reinsurance Corp, 935 F2d 1019, 1022-23 (9th Cir 1991).

91266 F3d 645 ( 7 th Cir 2001).

92 Id at 650.

93 Id. 
B. Cases Involving Bifurcation Agreements

In Hart Surgical, Inc v UltraCision, Inc, ${ }^{94}$ the First Circuit, relying on Metallgesellschaft, ${ }^{95}$ held that when the parties formally agree to bifurcate the liability and damages phases, a court has the power to review the arbitrator's decision after the arbitrator decides the liability issue, but before he or she determines damages. ${ }^{96}$

In Hart Surgical, the parties had entered into a contract in which Hart agreed to be the exclusive Canadian distributor for UltraCision's products. This contract contained an arbitration clause. A few years later, UltraCision terminated the distributorship for nonperformance. ${ }^{98}$ Upon commencing arbitration, the parties agreed to bifurcate the arbitration into liability and damages phases, with the approval of the arbitration panel..$^{\infty}$ The arbitrators decided that UltraCision was liable for wrongfully terminating the distribution agreement. ${ }^{100}$ UltraCision filed a motion to vacate that award. ${ }^{101}$ However, both parties agreed to stay the request in order to "facilitate a settlement" and "avoid the unnecessary expenditure of time and effort." The damages stage in arbitration stalled, and UltraCision urged the federal court to review the arbitrator's finding of liability. ${ }^{103}$

The district court dismissed UltraCision's motion, holding that under the FAA the award was not final, and therefore jurisdiction by the court was not proper. ${ }^{104}$ The court reasoned that since the parties had asked the arbitrators to decide both liability and damages, an appeal of only one of these decisions was akin to an interlocutory appeal and thus impermissible under the statute.

The First Circuit reversed the district court's decision and held that the district court had jurisdiction to review liability. ${ }^{106}$ Acknowledging the current circuit split, the court limited its holding to situations in which the parties have formally agreed to bifurcate at the arbitration stage. ${ }^{107}$

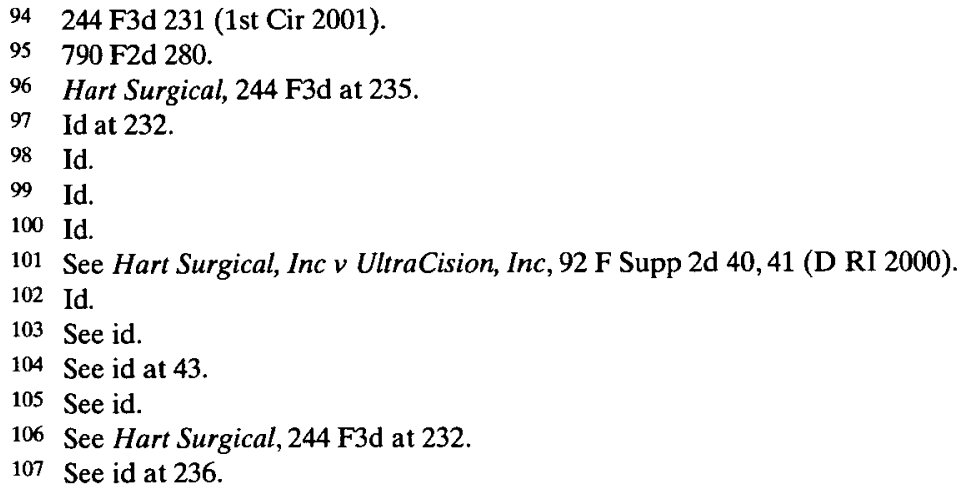


The First Circuit nevertheless extended Hart Surgical's reach in Providence Journal Co v Providence Newspaper Guild ${ }^{18}$ by permitting review of a partial arbitral award despite the lack of a formal bifurcation agreement. ${ }^{109}$ In that case, the parties arbitrated a dispute over the interpretation of a clause in their collective bargaining agreement. ${ }^{110}$ At the arbitration hearing, the parties informally agreed to bifurcate the proceedings into liability and damages." ${ }^{11}$ After the arbitrator found one party liable, he ordered the parties to try to negotiate an acceptable remedy but retained jurisdiction in case the parties failed. ${ }^{112}$

After the parties failed to reach an agreement, Providence Journal filed a motion in federal court to vacate the arbitral award, ${ }^{113}$ even though the arbitrator had not relinquished jurisdiction. The circuit court held that judicial review of a partial arbitral award was appropriate because the parties intended to bifurcate the phases-formality did not matter ${ }^{114}$ Furthermore, the court argued, if the arbitrator had not intended the decision on liability to be final, he would not have felt the need to state he was retaining jurisdiction over the remaining issues. ${ }^{115}$ Therefore, the court found review proper. ${ }^{116}$

The First Circuit has thus made a quick and sharp deviation from the finality requirement under the FAA. While the Seventh Circuit similarly has deviated from the rule, the doubts the court expressed in IDS Life Insurance may indicate that the court will move back to strict adherence to the final judgment rule.

\section{ADVANTAGES OF THE FAA's FINALITY REQUIREMENT}

This Part explains why enforcing partial arbitral awards violates the finality requirement in Section 10(a)(4) and contradicts the FAA's broader policies. It also answers the concerns that have led several

108271 F3d 16 (1st Cir 2001).

109 See id at 20. It is interesting to note that this decision was issued less than a year after Hart Surgical and both opinions were written by the same judge, Judge Juan Torruella.

110 Id at 18.

111 Id.

112 Id.

113 Id at 18.

114 See id at 19-20.

115 See id.

116 The court's conclusion is far from obvious. The arbitrator's statement can also be taken as evidence that the parties intended to fully resolve the dispute in arbitration. "It is a general rule in common law arbitration that when arbitrators have executed their award and declared their decision they are functus officio and have no power or authority to proceed further." $\mathrm{Mer}$ cury Oil Refining Co v Oil Workers International Union, CIO, 187 F2d 980, 983 (10th Cir 1951), disapproved of on other grounds by Textile Workers Union v Lincoln Mills, 353 US 448, 451 (1957). 
courts to loosen the finality requirement. First, arbitration is a creature of contract and allows parties to prevent more cumbersome arbitration proceedings, if they so desire. If they fail to do so, however, the court should not "rewrite" the parties' contract by providing a more streamlined process. Such action would benefit one party at the expense of the other. Second, the relaxed approach to finality undermines the FAA's goal of deferring to arbitrators by interfering before the arbitrator has used his or her expertise, for which he or she was hired, to decide the entire dispute. Third, analogies drawn to Rule 54(b) are inapt. There is no parallel provision in the FAA leading to the negative inference that Congress did not intend to authorize an exception to the final judgment rule. Further, Rule 54(b) permits interlocutory appeals only where the district court certifies that it is expeditious to do so. Courts that have exercised jurisdiction over partial arbitral awards by analogizing to Rule 54(b) have failed to even mention this important measure. Finally, it is not clear that a looser finality requirement will bring about a quicker, less expensive dispute resolution, as deviating courts hope.

\section{A. Arbitration Is a Creature of Contract}

One reason there is little cause for concern over the lack of piecemeal judicial review is that arbitration is a creature of contract. If there are circumstances unique to the parties, they can tailor their dispute resolution in a manner satisfactory to both sides. This weakens the argument that courts must intervene in order to protect parties from long, drawn-out disputes. In fact, courts should not allow piecemeal judicial review when the parties have not contracted for it because doing so rewrites the bargain that the parties struck ex ante.

1. Parties may craft the ground rules for arbitration.

Courts cannot justify judicial review simply on the need to ensure a speedy resolution to the parties' disputes. Arbitration gives the parties themselves the opportunity to craft the format and scope of any arbitration proceeding. Parties can require, for example, only one claim per arbitration proceeding. They can also limit the scope of discovery and evidentiary rules. ${ }^{117}$ These measures have a great effect on the length and breadth of any dispute resolution, and can control the scope of arbitration and avoid surprise. Hence, we should not be as worried about parties in an arbitration proceeding as we are about

117 See notes 20-23 and accompanying text. 
parties in litigation. It is more important to adhere to the parties' contract than to allow a court to rewrite their contract in an attempt to get a speedier resolution. The FAA was passed because when it came to arbitration clauses, courts failed to place parties' agreements on the same footing as other contracts. ${ }^{118}$ When time is of the essence, parties can ensure that time-saving devices are built into the contract. For example, the clause could provide that all issues raised in arbitration must be decided within six months. The agreed-upon arbitrator would have to agree to this time limit; the salary paid could be raised as needed for this to be accomplished. This addresses the Second Circuit's concerns over quick payment for freight, for example. If parties choose not to include this provision, then there is no reason for a court to be paternalistically concerned.

2. Existence of bifurcation agreements underscores parties' abilities to contract.

Arbitrations in which there is an agreement to bifurcate the proceedings and arbitrations in which there is not such an agreement pose conceptually different issues because in the former agreement the parties have contracted away from the default rules that the FAA provides. When the parties explicitly agree ex ante to divide up the arbitration, it is more convincing to allow judicial review of partial arbitral awards. This is subject, however, to the qualification that the parties in their agreement have explicitly agreed to judicial review of partial arbitral awards and not just requested that the arbitrator decide the issues sequentially via bifurcation. ${ }^{119}$ The fact that parties can agree to bifurcate indicates that the parties are capable of arranging for piecemeal judicial review. One reason why parties may agree to bifurcate liability and damages but not agree to piecemeal judicial review is because it is not clear that allowing judicial review of the liability phase before the arbitrator decides damages is quicker than allowing the arbitrator to determine both liability and damages before the district court reviews the awards.

The First Circuit has allowed judicial review of partial arbitral awards for cases in which the parties have a bifurcation agreement. In none of these cases, however, including Hart Surgical, ${ }^{120}$ did the parties explicitly agree to piecemeal judicial review. Furthermore, the reliance

118 See Part I.A.

119 Parties agree to bifurcate liability and damages because it is quicker to decide liability first. Then, if there is liability, the expensive process of discovery and hiring of experts can begin for the purpose of determining damages.

120 See Part II.B. 
on Metallgesellschaft, which did not contain a bifurcation agreement, indicates that the First Circuit may be willing to adopt the broader departure from the finality requirement.

3. Allowing review of partial arbitral awards effectively rewrites the parties' contract.

We should be bothered when courts attempt to change the process for which the parties bargained. By doing so, the courts are essentially rewriting the parties' contract, which helps one party (who benefits from the quick resolution) and hurts another (who benefits from proceeding in the way dictated by the agreement).

In addition, speed is not the sole consideration of the parties. If it were, both sides would agree to flip a coin to decide their disputes. Rather, parties voluntarily choose arbitration because they specifically want to avoid the courts and/or want an adjudicator with expertise in their field. To allow the courts to become involved in the process ahead of schedule is to upset the bargained-for contract by allowing judges to speak on the issues before the contracted-for expert has spoken on all of the issues involved in the dispute.

4. Judicial review of partial arbitral awards does not necessarily reduce costs and result in a speedier dispute resolution.

Even if speed and cost reduction were the sole considerations of the alternative dispute resolution process, ${ }^{121}$ it is far from clear that piecemeal review results in a quicker, cheaper resolution. Superficially it may appear to lower the expected cost of resolving a dispute because an affirmation of no liability saves both sides from the cost of disputing damages. However, this deviation from the finality requirement may burden society even more in terms of both time and money. The number of parties who will run to the public courts to seek interlocutory appeal will increase, putting a greater burden on taxpayers, not to mention the parties. ${ }^{122}$ It also may reduce the settlement range between the two parties. The expected value of the plaintiff's claim in-

121 Consider EEOC $v$ Waffle House, Inc, 534 US 279, 289 (2002) (stating that these were not the primary concerns of Congress when passing the FAA).

122 See Production and Maintenance Employees' Local 504, Laborers' Intl Union of North America, AFL-CIO v Roadmaster Corp, 916 F2d 1161, 1163 (7th Cir 1990):

Arbitration will not work if legal contests are its bookends: a suit to compel or prevent arbitration, the arbitration itself, and a suit to enforce or set aside the award. Arbitration then becomes more costly than litigation, for if the parties had elected to litigate their disputes they would have had to visit court only once. 
creases, while the expected loss by the defendant decreases, so they become less willing to bargain. ${ }^{123}$

\section{B. Deference to Arbitrators}

Deviating from the final judgment rule also changes the nature of the relationship between the judge and arbitrator. Federal arbitration policy mandates that arbitrators have the initial say in resolving the dispute. ${ }^{124}$ Indeed, a court does not have jurisdiction to consider the dispute until it has first been arbitrated except to decide whether to compel arbitration.

A direct analogy can be drawn to primary agency jurisdiction in administrative law. Under this regime, agencies possess primary jurisdiction over disputes arising in areas that fall within that agency's exclusive area of expertise. ${ }^{125}$ Courts do not assert jurisdiction until the agency has first decided the case before it. ${ }^{126}$ Similarly, just as the scope of review is limited by the FAA in the context of arbitration, so too is it constrained by the Administrative Procedure Act in the context of agency adjudication. Finally, the expertise concern is just as strong with agencies, since in both cases the primary decisionmaker possesses expertise lacked by the courts.

Allowing an expert to resolve the dispute is a primary reason parties contract for arbitration. ${ }^{127}$ Parties know that arbitrators have more

123 For an empirical study on the effects of bifurcation in traditional litigation, see William M. Landes, Sequential versus Unitary Trials: An Economic Analysis, 22 J Legal Stud 99 (1993).

124 See Rothlein v Armour \& Co, 391 F2d 574, 578-79 (3rd Cir 1968) ("[W]hen a comprehensive contractual procedure is available, such as arbitration, federal labor policy demands both initial recourse to such procedures and limited appeal from the decisions reached.") (citations omitted).

125 See, for example, Board of Education of City School District of New York v Harris, 622 F2d 599, 606-07 (2d Cir 1979) (citations omitted):

Primary agency jurisdiction is a flexible concept, concerned with "promoting proper relationships between the courts and administrative agencies charged with particular regulatory duties." It is called into play when a court, having unquestioned jurisdiction over a case involving matters governed by an administrative agency, determines which tribunal should make the initial adjudication, (Court's jurisdiction not ousted, but only postponed). The exercise of the court's discretion is guided in this situation by a desire for uniformity of regulation and the need for initial consideration by a body possessing special expertise in the issue presented.

126 "Congress has made clear its intent to favor arbitration by deferring to the expertise of arbitrators ... [by] 'requiring that [courts] rigorously enforce agreements to arbitrate." Davis v Prudential Securities, Inc, 59 F3d 1186, 1192 (11th Cir 1995), quoting in part Shearson/American Express, Inc v McMahon, 482 US 220, 226 (1987).

127 See David B. Lipsky and Ronald L. Seeber, In Search of Control: The Corporate Embrace of $A D R, 1 \mathrm{U}$ Pa J Labor \& Empl L 133, 138-39 (1998) (showing in a table that the top two reasons why corporations arbitrate - taking away the reasons 'required by contract' and 'more satisfactory process,' which only beg the question why-are 'limited discovery' ( 59.3 percent) 
expertise than judges in the parties' particular field, ${ }^{128}$ and parties often explicitly include a clause in their contract requiring that the arbitrator have such expertise. ${ }^{129}$ Courts, therefore, should not exercise jurisdiction to review the arbitrator's decision until the arbitrator, presumptively using his expertise, has decided the entire dispute. For just as the final judgment rule is motivated by concerns that subsequent developments in a case before a district court might greatly affect the significance of interlocutory decisions by the district court, it is just as likely that a final decision by the arbitrators will cast a partial award in a very different light. ${ }^{130}$

\section{Lack of Jurisdiction over Partial Arbitral Awards}

The final judgment rule has been a part of the federal judicial system since the first Judiciary Act of $1789 .{ }^{131}$ Exceptions to this rule have been few and well defined and were, for the most part, created in response to FRCP's creation of a broad civil action. ${ }^{132}$ Arbitration, on the other hand, is completely contractual and allows cumbersome proceedings to be avoided with forethought. Because Congress has not authorized piecemeal judicial review of arbitral awards, analogies to FRCP 54(b) are inapt in the FAA context.

1. Legislative approval is required for piecemeal review.

Congress did not authorize judicial review of partial arbitral awards, and regardless of whether it may be desirable to allow such review in limited circumstances, that is a policy judgment for Congress to make - not the courts. Until Congress acts, the courts must exercise judicial restraint and not act unilaterally. Since the ratification of our Constitution, courts have recognized that the "disposal of judicial power ... belongs to congress.",133 Beyond those powers the Constitution specifically gives the courts, additional judicial powers lie exclusively in Congress's hands.

and 'expertise' (49.9 percent)).

128 See, for example, Litton Financial Printing $v$ NLRB, 501 US 190, 213 (1991) (acknowledging that arbitrators typically have more expertise in construing collective-bargaining agreements than courts do).

129 See, for example, CPR (USA) Inc v Spray, 187 F3d 245, 256 (2d Cir 1999) (parties included an arbitration clause specifying that the arbitrator must have expertise in Going Concern Value "if the dispute concerns a determination with respect to the Special Bonus Pool").

130 See Part I.B.

131 See Cunningham v Hamilton County, Ohio, 527 US 198, 203 (1999). See also Part I.B.

132 See note 52 and accompanying text.

133 Turner v Bank of North America, 4 US (4 Dall) 8, 10 n 1 (1799). 
Courts that have made an exception to the FAA's finality requirement have overwhelmingly drawn analogies to Rule 54(b). They hope to "avoid the possible injustice of a delay in judgment of a distinctly separate claim" have been adjudicated. ${ }^{135}$ Their attempts to analogize judicial review of partial arbitral awards to interlocutory review under FRCP 54(b) do not survive close scrutiny.

FRCP 54(b) was created through an explicit amendment to the rules of civil procedure modifying the final judgment rule. Without Congress's approval, the appellate courts would not have the authority to review district court claims before the entire case had been decided. The Supreme Court has stated that in the task of construing statutes, it is "entirely sensible" for a court to draw negative inferences from various sections in the statutes. ${ }^{136}$ Since the FAA has not been amended to include an exception similar to Rule 54(b), a negative inference can be drawn that such an exception is not authorized. This negative inference is further strengthened by the fact that since the Act's conception, Congress has continued amending the FAA, but has never seen fit to loosen the finality requirement. ${ }^{137}$

2. Rule 54(b) requires district court certification.

Rule 54(b) includes a safety valve that limits the rule's effect on the final judgment rule. It is not enough for a lower court to enter a "final" judgment for one, but not all, of the claims. There still can only be appellate judicial review for that claim "upon an express determination that there is no just reason for delay and upon an express direction for the entry of judgment." ${ }^{, 138}$ If the district court does not make such a determination, the appellate court will not have jurisdiction. This provision allows district judges to exercise their judgment and anticipate when piecemeal review will be beneficial for both the parties and the courts. In the cases granting judicial review of partial arbitral

134 FRCP 54(b), Advisory Committee Note to the 1946 Amendments.

135 See id. See also, for example, Metallgesellschaft $A G \vee M / V$ Capitan Constante $790 \mathrm{~F} 2 \mathrm{~d}$ 280 (2d Cir 1986) ("It would be a perversion of this salutary design for a [party] to be denied ... prompt and commercially important relief.").

136 See, for example, Lindh v Murphy, 521 US 320, 336-37 (1997); Sandin v Conner, 515 US 472, 481 (1995).

137 For example, in 1988 Congress amended the FAA to permit parties in certain situations to allow for the immediate appeal of orders enjoining arbitration. Judicial Improvements and Access to Justice Act, Pub L No 100-702 $\S 1019,102$ Stat 4670 (1988), codified as amended at 9 USC $\S 16$. This was intended to ensure that parties were not forced to wait until a trial has been completed to appeal the denial of arbitration. See id.

138 FRCP 54(b). 
awards, the arbitrator did not make such determinations. Rather, the courts decided for themselves whether review was timely and desirable.

Cases such as Metallgesellschaft and Publicis, which allow judicial review of partial arbitral awards, invoke the policy rationale of FRCP 54(b), but do not adhere to the safeguard found in the rule. These cases go farther than FRCP 54(b), because FRCP 54(b) has been interpreted not to apply to cases where there is a single claim, but rather just two phases of the same claim. ${ }^{139}$ Yet, in Hart Surgical, this is exactly what the court permitted. Not adhering to safeguards is dangerous because it undermines the bargain that the parties have contracted for and more often than not results in longer delays of justice. ${ }^{14}$

Allowing arbitrators to sign off on allowing judicial review of a partial arbitral award, however, is not a sufficient solution. The arbitrator cannot exceed his or her power, which is defined by the parties' agreement. To do so can result in the award being vacated under Section 10(a)(4) of the FAA. Parties have the power to tailor their contracts to their needs; if parties choose not to, the court should not alter the bargained-for contract ex post. Doing so would benefit one party at the expense of another. Also, FRCP 54(b) was not meant to overturn the settled federal rule of prohibiting piecemeal disposal of litigation. ${ }^{141}$ Avoiding review before the entire case has been decided is a rule that can be traced back to early English common law. ${ }^{142}$ Given

139 See, for example, Williams v St. Louis Diecasting Corp, 611 F2d 1223, 1224 (8th Cir 1979) (explaining why FRCP 54(b) is not a valid basis for appeal); Western Geophysical Co of America $\checkmark$ Bolt Associates, Inc, 463 F2d 101,102 (2d Cir 1972) (stating that "a judgment determining liability but not fixing damages is not final" for the purposes of FRCP 54(b)).

140 See Metallgesellschaft, 790 F2d at 285 (Feinberg dissenting) ("[I]n the long run, I fear that confirmation of such separate and independent claims will make arbitration more complicated, time consuming and expensive."). See also Landes, $22 \mathrm{~J}$ Legal Stud 99 (cited in note 123); Part I.A.

141 See FRCP 54(b), Advisory Committee Note to the 1946 Amendments ("The historic rule in the federal courts has always prohibited piecemeal disposal of litigation ... [Rule 54(b)] was not designed to overturn the settled federal rule.").

142 See Hohorst $v$ Hamburg-American Packet Co, 148 US 262, 265 (1893), quoting Holcombe v McKusick, 61 US (20 How) 552, 554 (1857):

It is the settled principle of this court, and the same in the King's Bench in England, that the writ will not lie until the whole of the matters in controversy in the suit below are disposed of. The writ itself is conditional, and does not authorize the court below to send up the case, unless all the matters between the parties to the record have been determined.

See also United States $v$ Girault, 52 US (11 How) 22, 32 (1850) ("The writ is conditional, and does not authorize the court below to send up the case unless all the matters between all the parties to the record have been finally disposed of. The case is not to be sent up in fragments, by a succession of writs of error."); Houston v Moore, 16 US (3 Wheat) 433, 434 (1818) ("The appellate jurisdiction of this court, under the 25 th section of the judiciary act, ch. 20 . extends only to a final judgment or decree of the highest courts of law or equity in the cases specified."). 
that the Advisory Committee did not want to overturn this rule, it is clear that courts do not have the legislature's approval to review arbitral awards beyond the scope listed here.

\section{CONCLUSION}

At first blush, the differences between allowing an appeal from a non-final decision by a district court judge for review in an appellate court and allowing an appeal from a partial arbitral award by an arbitrator for review in a district court seem trivial. However, they are not. Congress has not authorized appeals of partial awards by arbitrators. Furthermore, a loose finality requirement undermines the goals of deference to the arbitrators and the potential advantages gained due to the arbitrator's expertise. Finally, arbitration is a creature of contract and requires affirmative agreement before a party can be bound. Parties can address potential problems ex ante. Any attempt to address problems ex post rewrites the deal that the parties bargained for and should be avoided. Courts should therefore strictly enforce the finality requirement of 9 USC $\S 10(a)(4)$ unless Congress decides otherwise. 


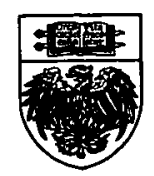

